\title{
Direct effects of dominant winds on residence and travel times in the wide and open lacustrine embayment: Vidy Bay (Lake Geneva, Switzerland)
}

\author{
A. M. Razmi - D. A. Barry • U. Lemmin • \\ F. Bonvin · T. Kohn • R. Bakhtyar
}

Received: 26 February 2013/ Accepted: 10 October 2013/Published online: 23 October 2013

(C) Springer Basel 2013

\begin{abstract}
Numerical simulations were carried out to determine the residence (or flushing) time of water in Vidy Bay (north shore of Lake Geneva) for different meteorological conditions. A hydrodynamic model (Delft3DFLOW) was applied to simulate the flow field in the embayment during 2010 and January 2011. Using these results, particle tracking was applied to estimate transport of wastewater effluent discharged into the embayment. The model predictions compared well with published field measurements of dissolved species (as given by electrical conductivity profiles) within the wastewater. The pelagic boundary of the embayment was defined by the largest within-bay gyre. Based on this definition, particle tracking was used to quantify the residence time under dominant wind conditions. Similarly, particle tracking was used to determine the travel time (i.e., time to exit the embayment)
\end{abstract}

This article is part of the special issue "éLEMO - investigations using MIR submersibles in Lake Geneva".

Electronic supplementary material The online version of this article (doi:10.1007/s00027-013-0321-8) contains supplementary material, which is available to authorized users.

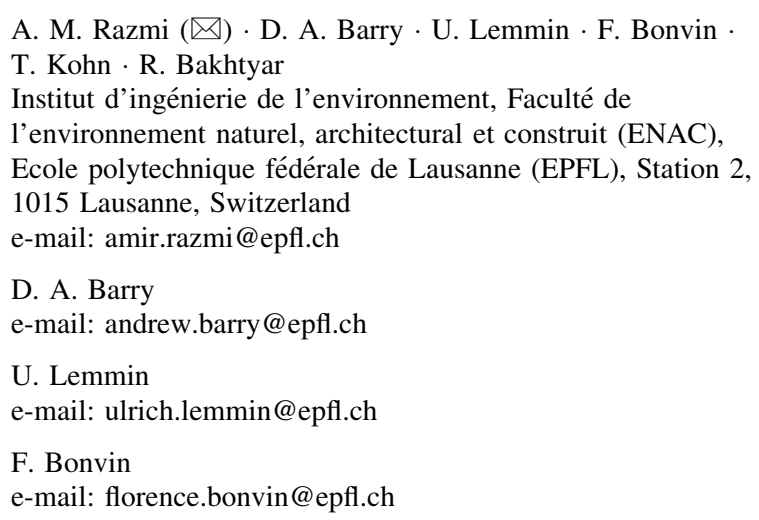

for each of Vidy Bay's three inflows (stream, stormwater and wastewater effluent). Although the wind field over the lake is variable, current patterns in the embayment can be simulated using the hydrodynamic model forced by a spatially uniform wind field. For a given wind speed, the main factor influencing residence and travel times is the wind angle. The presence of gyres leads to high mean residence times with large variability. As the wind direction becomes more aligned with the shoreline (i.e., with increasing westerly or easterly components), longshore currents dominate. These disrupt gyre formation and markedly reduce the mean and variability of embayment residence time. The numerical model was utilized to assess the potential for plume movement (in plan) from above the wastewater effluent outfall towards one of Lausanne's drinking water intakes. In the most direct pathway, westward longshore currents can move water from the embayment to the water column above the intake location.

Keywords Delft3D - Hydrodynamics - Particle tracking · Gyre - Dominant winds - Wastewater effluent

\author{
T. Kohn \\ e-mail: tamar.kohn@epfl.ch \\ R. Bakhtyar \\ e-mail: roham.bakhtyar@unc.edu \\ Present Address: \\ R. Bakhtyar \\ Department of Environmental Sciences and Engineering, \\ The University of North Carolina, Chapel Hill, \\ NC 27599-7431, USA \\ R. Bakhtyar \\ Coastal and Hydraulics Laboratory, US Army Engineer Research \\ and Development Center, Vicksburg, MS 39180-6133, USA
}




\section{Introduction}

Lakes and reservoirs serve multiple purposes (Brookes et al. 2004; Wüest et al. 2013). Apart from providing clean and safe drinking water, they can be recreation centers, have high cultural value, and provide numerous ecosystem services (e.g., Ge et al. 2010; Ji 2008; Kristal et al. 2005). Urbanization and extensive agricultural use of lake/reservoir catchments are responsible for increased pollutant loads to such water bodies, e.g., Canyon Lake in California (Kristal et al. 2005), Myponga Reservoir in South Australia (Brookes et al. 2004; Hipsey et al. 2008), Sugarloaf Reservoir in Victoria, Australia (Hipsey et al. 2008), or Billings Reservoir in Sao Paulo, Brazil (Hipsey et al. 2008). The occurrence of micropollutants such as pharmaceuticals and pesticides in natural water bodies is a prevalent, contemporary issue. For example, roughly half of the micropollutant (e.g., pharmaceuticals) load is not removed in typical wastewater treatment plants (WTPs) and is released to receiving waters (Oulton et al. 2010).

Along with environmental and meteorological conditions, lake hydrodynamics play a prominent role affecting the fate of pollutants (George and Edwards 1976; Harris et al. 2004; Okubo 1973; Scavia and Bennett 1980). Nearshore hydrodynamic processes affect the variability of solute concentrations in littoral zones and are important for determining their dispersal in the lake. For instance, the accumulation of dissolved components in a given zone depends on the rate at which the water in that zone is replaced, as well as on transformation processes. More precisely, a major control on pollutant fate is the hydrodynamic residence time in the region of interest. Indeed, analysis of residence time in a lake's littoral zone is essential for realistic assessment of environmental conditions affecting water quality (Falconer et al. 1991; Schladow and Hamilton 1997; Choi and Lee 2004).

Embayment hydrodynamics in response to wind forcing have not been extensively studied. Most investigations are from physical/coastal oceanography, but not on open lacustrine embayments as commonly found in lakes (Rueda and Cowen 2005). The difference in physical circumstances is substantial. In coastal oceans, nearshore water exchange is generated by interactions of tides and waves (Singell et al. 1990), neither of which are factors in most lakes. Razmi et al. (2013) categorized lake embayments based on their geomorphological features, viz., geometrical characteristics (in plan) and, in the vertical, presence of a summer thermocline. They analyzed the hydrodynamics of Vidy Bay in detail. As described in the Editorial to this Special Issue (Wüest et al. 2013), Vidy Bay (Fig. 1a) is particularly relevant for investigation of residence and travel times as it receives wastewater discharges from the Lausanne WTP outfall, as well as Lausanne stormwater
(Flon drain) and inflow from the Chamberonne River (which drains a mixed urban/agricultural catchment). Each of these inputs to the embayment is a source of anthropogenic chemicals, in which case lengthy periods of nearshore water entrapment have the potential to influence water quality within the embayment and the associated sediments (Gascon Diez et al. 2013; Hoerger et al. 2013; Masson and Tercier-Waeber 2013; Sauvain et al. 2013; Wunderlin et al. 2013).

Here, we build on the investigation of Razmi et al. (2013) and consider the distribution of residence times within Vidy Bay, as an archetype of a wide and open embayment. Our goal is to evaluate the direct response of wind forcing on the residence (or flushing) time of water within this embayment. We consider also the transport of water from the main inputs to the embayment, as these are potential sources of anthropogenic pollution. Specifically, travel times to exit the embayment are estimated. Finally, as an example for which the methodology employed is particularly apt, we examine the potential for wastewater released into the embayment from the WTP to reach the vicinity of the nearby withdrawal point for the Lausanne drinking water supply.

\section{Modeling approach}

Synthetic scenarios were defined based on the dominant wind regimes and seasonal stratification. Lagrangian particle tracking was applied to calculate the residence time for the whole embayment, as well as travel times for inputs into it. The particle tracking results were compared with previously reported field data of Bonvin et al. (2011), as described below.

\section{Study site}

Lake Geneva (surface area of $580 \mathrm{~km}^{2}$, maximum and average depth of $310 \mathrm{~m}$ and $153 \mathrm{~m}$, respectively, and maximum length and width of 72 and $14 \mathrm{~km}$, respectively) is the largest freshwater resource in western Europe, and the main drinking water source for more than 600,000 people (Cipel 2013). Several WTP outfalls discharge effluent in the lake's littoral zones. The Lausanne WTP discharges more than $100,000 \mathrm{~m}^{3}$ day $^{-1}$ of treated wastewater at a depth of $30 \mathrm{~m}, 500 \mathrm{~m}$ offshore of Vidy Bay (Fig. 1a) (Hoerger et al. 2013; Margot et al. 2013). A major drinking water intake is located at St. Sulpice at a depth of $50 \mathrm{~m}$ about $2 \mathrm{~km}$ to the west of Vidy Bay (Fig. 1a, or $3.7 \mathrm{~km}$ from the WTP outfall). Conventional wastewater treatment often consists of several phases: primary treatment (sedimentation), secondary treatment (biological) and at times a tertiary treatment (physico-chemical) to remove 
Fig. 1 a Location of Lake Geneva and map of Vidy Bay. The WTP outfall, drinking water intake and Pully weather station are identified, along with lake depth contours. Vidy Bay lies on the northern boundary of the Grand Lac. Red circles locate three (i-iii) sampling sites accessed in 2010 and January 2011 for micropollutant plume detection (Bonvin et al. 2011). b Simulated vorticity contours in Vidy Bay for the largest gyre (after Razmi et al. 2013). The color background shows the amount of vorticity $\left(\mathrm{s}^{-1}\right)$. The black, solid lines (rectangular sides plus shoreline) define the embayment boundary, which is motivated by the zero vorticity line. The (cross symbols) mark the release points of particles in numerical simulations. Eastings and Northings refer to the Swiss Coordinate system, CH1903

(The Swiss coordinates 2013) (color figure online)
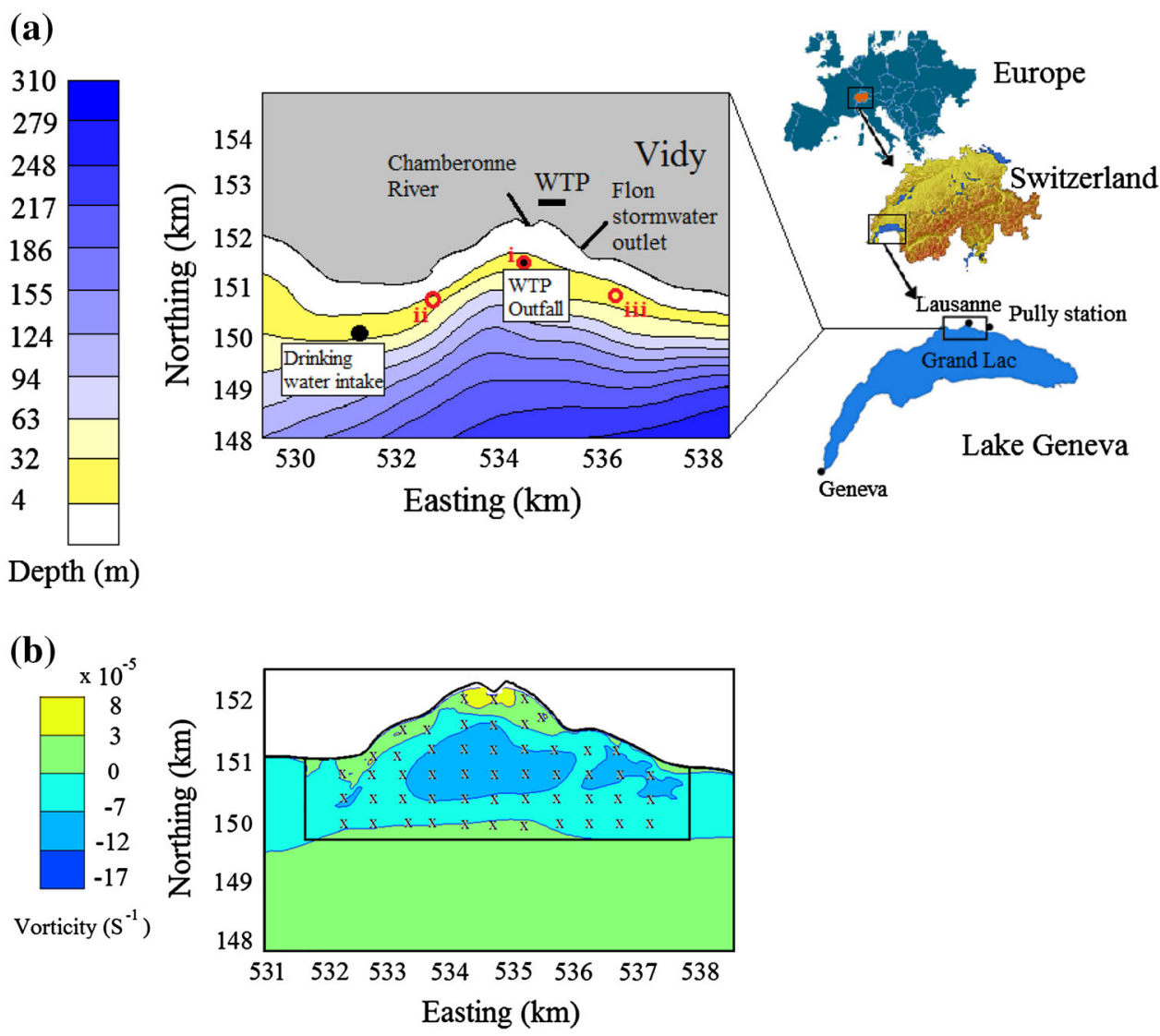

phosphorus and nitrate (Daughton and Ternes 1999). Numerous studies have shown that many micropollutants are often not eliminated by conventional WTPs (Daughton and Ternes 1999) and recent investigations at the Vidy WTP confirm that its effluent contains low concentrations of micropollutants such as pharmaceuticals (Margot et al. 2013).

The littoral/pelagic boundary of Vidy Bay must be defined before residence times can be computed. Razmi et al. (2013) determined this boundary based on the largest nearshore gyre (computed for 2010 and 2011). The calculated vorticity for this gyre is shown in Fig. 1b. The left and right boundaries of the embayment are given by the shoreline changes, while the offshore boundary is derived from the zero vorticity line. We note that this means for defining the embayment, although intuitive, does not correspond to the embayment's geometry. Rather, it locates the littoral/pelagic boundary of the embayment somewhat offshore than might be expected from purely geometrical considerations.

Wind is the main source of current variability in Lake Geneva (Bohle-Carbonell 1986). Statistical analysis of meteorological station data identified two main wind directions: one from north/northeast (locally termed the Bise) and the other from the south/southwest (locally termed the Vent, Lemmin and D'Adamo 1996). These wind analyses were confirmed by Razmi et al. (2013), who analyzed data from the closest meteorological station to Vidy Bay (Pully station, shown in Fig. 1a, is located about $3 \mathrm{~km}$ east of Vidy Bay).

Razmi et al. (2013) found that the time required for gyre formation in Vidy Bay is about $6 \mathrm{~h}$ for a moderate wind $\left(\sim 3 \mathrm{~m} \mathrm{~s}^{-1}\right)$. Also, analysis of over 20 years of meteorological records from nearby Pully station (Haldimann 2010) showed that Bise and Vent wind regimes are much more frequent ( $\sim 90 \%$ of the time) than other wind regimes. The duration and reoccurrence time based on Pully station measurements were determined by Razmi et al. (2013). Winds in the range $0^{\circ}-70^{\circ}$ (degrees azimuth) were denoted as Bise, winds in the range $170^{\circ}-320^{\circ}$ as Vent, and the rest as Others (Table 3). The recurrence time of wind events of a given duration were calculated. For a wind duration of $6 \mathrm{~h}$, the recurrence times (i.e., time interval until the next wind event of at least $6 \mathrm{~h}$ ) of Bise and Vent were, on average, $\sim 14$ and $\sim 23 \mathrm{~h}$, respectively. The average recurrence time of others was much greater ( $190 \mathrm{~h}$ ).

Wind fields over Lake Geneva are spatially variable (note that above the wind angles were defined based on the Pully meteorological station). Razmi et al. (2013) considered spatially variable (as given by COSMO (2013) and homogeneous (with direction defined at Pully) wind fields 
in their hydrodynamic modeling, and found that gyre formation in Vidy Bay is similar for each case. This is a useful result, since it means that Vidy Bay's gyres can be examined systematically using homogeneous wind fields.

There are two qualitatively different scenarios for current patterns in Vidy Bay. First, gyres entrap the water within the embayment and increase the residence time. In contrast, second, longshore currents flush the water from the embayment rapidly. Razmi et al. (2013) showed that the wind angle is the critical factor controlling the occurrence of these two situations-both are examined in the following. In doing so, we are in a position to evaluate the main sources of variability in Vidy Bay's residence times. Note that we consider uniform winds, and do not evaluate changes in currents that occur due to relaxation of the wind forcing.

Diurnal winds driven by land-lake temperature differences occur in summer in Lake Geneva, and are negligible in winter. Field investigations on the effect of the diurnal winds on transport in the near-shore zone of Vidy Bay showed that they influence near-surface currents, e.g., above $3 \mathrm{~m}$ depth (Lemmin and D'Adamo 1996). In summer, however, wastewater effluent is typically trapped below the thermocline. Thus, diurnal winds were not considered.

\section{Numerical modeling}

\section{Hydrodynamic model, validation, and calibration}

Currents in the embayment were simulated using a three dimensional (3D) finite-difference hydrodynamic model (Delft3D-FLOW 2013). The model solves the ReynoldsAveraged Navier-Stokes equations in sigma coordinates using a $k$ - $\varepsilon$ turbulence closure for an incompressible fluid with the Boussinesq approximation and hydrostatic assumption (Lesser et al. 2004). Temperature is the main driver of density changes in waters of Lake Geneva. The surface heat budget was calculated using the ocean heat flux model (Gill 1982), which computes the net heat flux through the surface accounting for shortwave radiation, effective longwave radiation, evaporation, and the convective heat flux.

Based on computational runtime and convergence and stability criteria, a non-uniform mesh $\left(1.8 \times 10^{6}\right.$ grids for the entire lake) and a time step of $1 \mathrm{~min}$ were imposed. The lake was discretized using a variable mesh-size grid in the horizontal ( $\sim 45,000$ cells), with a finer mesh (minimum $\sim 40 \times 60 \mathrm{~m}^{2}$ ) in Vidy Bay.

A 40-level, non-uniform vertical mesh with finer grid sizes in the upper levels was used. The vertical grid thicknesses above the Vidy Bay outfall were (surface to lakebed) $2 \times 0.18,2 \times 0.27,22 \times 0.315,0.42,0.57$,
$3 \times 0.69,0.84,1.2,1.5,1.92,3 \times 2.55$ and $2 \times 3 \mathrm{~m})$. The results did not change significantly with the mesh refinement (Table S1) ("S" refers to Supplementary Data). The Chezy roughness formula with a Chezy value of $65 \mathrm{~m}^{1 / 2}$ $\mathrm{s}^{-1}$ was used (Soulsby 1997; Lesser et al. 2004) after sensitivity analysis (Table S2). Variable surface roughness was selected (Wüest and Lorke 2003). The wind drag coefficient in the model was considered to be piecewise linearly dependent on the wind speed, as described in the Supplementary Data.

The surface forcing conditions were given via high resolution ( $\sim 2.2-\mathrm{km}$ grid) meteorological data (COSMO 2013). These data were based on the assimilation cycle of the COSMO weather forecast model of MeteoSwiss. COSMO is the nested portion (located over Switzerland) of the continental-scale weather forecasting model. The data provided by COSMO include hourly wind, pressure, temperature, relative humidity and cloudiness percentage. To obtain accurate numerical predictions, each year was divided into four periods of 3 months. We considered a 20-day spin-up time for each run. Conditions at the start of each period were made consistent with seasonality (e.g., background eddy vertical diffusivity coefficient). After sensitivity analysis (Table S2), $10^{-4}$ and $10^{-5} \mathrm{~m}^{2} \mathrm{~s}^{-1}$ were used for the non-stratified and stratified conditions, respectively, for the background and vertical eddy diffusivities. Secchi depths of 5 and $10 \mathrm{~m}$ were used for stratified and non-stratified seasons, respectively. Moreover, observed temperature profiles (CTD measurements above the outfall) were used at the beginning of each run.

Model calibration and validation focused on Vidy Bay. Previously, simulated horizontal velocity and temperature profiles were found to compare reasonably well with Vidy Bay measurements (ADCP, CTD and Lagrangian drifter data) (Razmi et al. 2013). Additional validation of the hydrodynamic model was achieved by comparison of 50 days of ADCP observations collected during 1 October20 November 2005 (Fig. S1). The model (mean RMSE of $1.8 \mathrm{~cm} \mathrm{~s}^{-1}$ ) was able to capture the major events in the observed time series, particularly the large scale processes.

\section{Particle tracking model}

The hydrodynamic model was run for 2010 and January 2011. Current velocity fields from Delft3D-FLOW were subsequently used to drive particle tracking (Delft3DPART), so as to simulate transport of water parcels ("particles"). Delft3D-PART models both advection (as given by the local velocity vector) and diffusion/dispersion (an additional random step) (Delft3D-PART User Manual 2009), with the size of the step chosen to replicate the predetermined horizontal and vertical eddy diffusivities. 
In the particle tracking module, vertical diffusivity values of $10^{-4}$ and $10^{-5} \mathrm{~m}^{2} \mathrm{~s}^{-1}$ were selected for nonstratified and stratified conditions, respectively (e.g., Wüest and Lorke 2003). Different horizontal diffusivity coefficients suggested by Peeters et al. (1996) were checked $\left(0.05-0.5 \mathrm{~m}^{2} \mathrm{~s}^{-1}\right)$. Within this range, $0.3 \mathrm{~m}^{2} \mathrm{~s}^{-1}$ was selected for the effective horizontal eddy diffusivity after calibration. Note that the modeling approach does not account for small-scale local mixing. Rather, it is expected to capture transport and mixing due to mean currents and larger-scale eddies that a solute plume would experience in the embayment. For the embayment residence time simulations, particles were released from each model grid cell within Vidy Bay (see Fig. 1b, where cell centers are indicated by x's). Particles were distributed uniformly throughout these cells at a density of 1 particle per $5 \times 10^{4} \mathrm{~m}^{3}$.

\section{Residence time calculation}

The Lagrangian model used to calculate the residence time was (Buffoni et al. 1997; Jackson et al. 2012):

$N_{e}(t)=N(0)-N(t)$,

$N(0) T^{*}(t)=t N(t)+\sum_{i=0}^{N_{e}(t)} t_{e i}$,

$T=\lim _{t \rightarrow \infty} T^{*}(t)$

where $N(0)$ is the number of particles inside the embayment at release $(t=0), N(t)$ is the number of particles that are still inside the embayment at time $t, N_{e}(t)$ is the number of particles that have escaped the boundary up to time $t, t_{e i}$ is the escape time of $i$ th particle, $T^{*}$ is the residence time estimator at time $t$, and $T$ is the residence time. Note that particles are considered as non-reactive tracers.

Field measurements

Bonvin et al. (2011) described a field sampling campaign that measured micropollutant concentrations in Vidy Bay approximately once per month for 10 months (in 2010 and January 2011). Information on sampling intervals and depths, instruments and their precisions was given in detail by Bonvin et al. (2011). EC profiles were collected at various depths at three embayment locations: the WTP outfall ("i" in Fig. 1a) and two other sites located $1.5 \mathrm{~km}$ from the outfall in both parallel-to-shore directions ("ii" and "iii" in Fig. 1a). Bonvin et al. (2011) showed that EC profiles can serve as a proxy for micropollutant concentrations, as is the case for ionic species. For $E C$ values up to about $1,500 \mu \mathrm{S} \mathrm{cm}^{-1}$ (in Vidy Bay typical values are in the range $300-400 \mu \mathrm{S} \mathrm{cm}^{-1}$ ), the concentration of ionic species is linearly proportional to EC (Appelo and Postma 2005). In addition, Bonvin et al. (2013) showed that several micropollutants are not degraded within the embayment, at least on the time scales of their sampling campaigns. Thus, we treat the $E C$ measurements of Bonvin et al. (2011) as representing a dissolved tracer suitable for comparison with results of the particle tracking model described above.

Bonvin et al. (2011) selected the sampling locations "i"-“iii" to capture the (assumed frequent) parallel-toshore movement of the WTP effluent plume. However, they detected elevated $E C$ (and micropollutant concentrations) only on two occasions, 7 April and 6 October. Nonetheless, their $E C$ data provides a valuable constraint on the predictions of the hydrodynamic model in terms of the current directions predicted for the sampling dates. Where elevated $E C$ was detected, their data are also valuable for checking the particle tracking model predictions, since in that case dilution (meaning reduction in EC) can be compared.

\section{Results and discussion}

Comparison with field data of Bonvin et al. (2011)

As mentioned, currents in Lake Geneva were modeled for 2010 and January 2011 meteorological data using Delft3DFLOW (2013). Using these results, particle tracking simulations were performed for each set of sampling data reported by Bonvin et al. (2011). Table S3 reports the wind characteristics at the time of each experiment. We focus here on the 7 April data (plume detected), and contrast these with data of 3 May (no plume detected). Corresponding results for the other eight samplings are given in figure S2. To compare with these profiles, we released particles in grid cells in the water column above the WTP outfall, and tracked their subsequent movement. Particles were released above the outfall below the thermocline where the micropollutant concentrations were trapped. For the initial location of the released particles, we assumed that the WTP effluent plume's vertical movement due to buoyancy was complete. Thus, in the model, particles had the same density as that of the surrounding water, at the given vertical location.

Particle concentrations at each time step were calculated by counting particles within computational cells, and were scaled using the concentrations at the release point (1 particle per $40 \mathrm{~m}^{3}$ ). This predicted relative concentration $(C)$, as given by the particle tracking results, quantifies the "dilution" mentioned above. The corresponding quantity, $E C_{r e l}$, determined from the $E C$ data is: 
$E C_{r e l}=\frac{E C-E C_{\text {back }}}{E C_{\max }-E C_{\text {back }}}$,

where $E C_{\text {back }}$ is the background $E C$ and $E C_{\max }$ is the maximum $E C$ measured above the WTP outfall on the day of sampling. Thus, predicted profiles were calculated using:

$E C_{\text {pred }}=\left(E C_{\max }-E C_{\text {back }}\right) C+E C_{\text {back }}$.

On 7 April, a peak in $E C$ was measured at site "ii" at about 8-m depth (Fig. S2a). A noticeable thermal variation in the water column from the surface to about 8-m depth was observed. The temperature profile in figure S2a shows some local increases (e.g., at $12 \mathrm{~m}$ depth), consistent with the presence of the outfall plume.

The sampled EC profiles of Bonvin et al. (2011) indicated that the outfall effluent was trapped below the thermocline and then transported horizontally. Figure S2b presents the $E C$ profile for 3 May where, in contrast to figure S2a, little change in $E C$ was detected. For the 7 April measurements (Fig. S2a), $E C_{\text {back }}$ was about $310 \mu \mathrm{S} \mathrm{cm}{ }^{-1}$ at both the WTP outfall point (location "i") and location "ii". The maximum $E C$ above the outfall was about $455 \mu \mathrm{S} \mathrm{cm}^{-1}$, with a corresponding $E C$ value of about $330 \mu \mathrm{S} \mathrm{cm}^{-1}$ at location "ii", giving an estimated observed dilution factor (i.e., $E C_{r e l}$ ) of about 0.14 between these two points. This value is slightly higher than that found from numerical modeling (about 0.1). Figure S2 also reports predictions $\left(E C_{\text {pred }}\right)$ of the $E C$ profiles from the particle tracking. The results in figure $\mathrm{S} 2 \mathrm{a}$ show reasonable agreement between the predicted and measured $E C$ profiles (averaged RMSE of $\sim 2.8 \mu \mathrm{S} \mathrm{cm}^{-1}$ and mean bias of $\sim 1.9 \mu \mathrm{S} \mathrm{cm}^{-1}$ ). Clearly, the data are insufficient for further investigation of the validity of the eddy diffusivities used in the particle tracking model. However, it appears that the selected values of these parameters are consistent with the measured data. Also, the predicted temperature profiles (calculated using Delft3D-FLOW) are in reasonable agreement with the field data (RMSE was less than $\sim 2{ }^{\circ} \mathrm{C}$ ).

As shown in figure S2, the EC and temperature predictions, considering all the sampling events, are consistent with the measured data, even if no elevated EC values were measured except for 6 October. This consistency in predicting solute transport and temperature profiles, combined with our previous modeling of Vidy Bay's currents (Razmi et al. 2013), suggests that the model is suitable to estimate residence times under different meteorological conditions in this embayment.

Preliminary modeling indicated that the travel time from the WTP outfall to site "ii" at the time of sampling was close to $6 \mathrm{~h}$ on 7 April. Guided by the temperature profile, particles were released at each time step for $6 \mathrm{~h}$ over the depth of 5-15 m on 7 April and 15-20 m on 3 May above the WTP discharge point, at which time the particle concentrations in each model cell were calculated. Figure 2 shows plan views of the relative particle concentrations at two different layers in the water column. For 7 April (Fig. 2a, b), the plume movement is towards the west and parallel to the shoreline. The passage of the plume past sampling point "ii" is clear, with higher concentrations at the 8-10 m depth than at 4-6 m. On 3 May, the simulated plume moved more towards the northeast, hence no concentration peaks were observed at location "ii" on that day, nor did it reach location "iii" subsequently (results not shown). We observe also that, even though the outfall is located $500 \mathrm{~m}$ offshore, the WTP discharge on 7 April is predicted to reach the shore within hours (Fig. 2a, b). Note that on 3 May, the $E C$ profile shows a step change (15-20 m depth) above the WTP outfall, which is not replicated by the model. The "step" profile was observed at all sampling locations (i, ii, and iii, Fig. 1a). On this date, the hydrodynamic model showed onshore currents from the pelagic zone into Vidy Bay (Fig. S3 and Fig. 2c, d). This suggests that the water moved from the pelagic zone and entered the epilimnion in Vidy Bay and that the stratification prevented mixing of the hypolimnion and epilimnion. We have no direct measurements of the $E C$ profile offshore of Vidy Bay on 3 May, and thus to replicate the observations in the model it would be necessary to impose a suitable off-shore $E C$ profile, in which case the model would predict the observations.

\section{Residence times for different characteristic wind} regimes and thermal stratification

Razmi et al. (2013) investigated the main currents induced by the dominant wind regimes (Bise and Vent) in Vidy Bay. They found that the flow field can be directed eastwards or westwards along the shore, as well as offshore, depending on the wind direction. In addition, both field data and numerical simulations indicated that gyres form in the embayment in some circumstances. The mechanism for gyre formation was determined to be the combination of local wind direction and relatively small changes in large scale gyres in the large basin of Lake Geneva. In short, winds (categorized as either Vent or Bise) can induce gyres (or not) in Vidy Bay, depending on the wind angle.

Extensive numerical investigations showed that typical circulation patterns in Vidy Bay can be modeled using uniform wind fields over the entire lake (Razmi et al. 2013). This finding makes a systematic analysis of currents under different wind angles feasible, assuming uniform winds over the entire lake. It was found that gyre formation occurs (or disappears) at particular wind angles; i.e., currents in the embayment can switch from being longshore to 

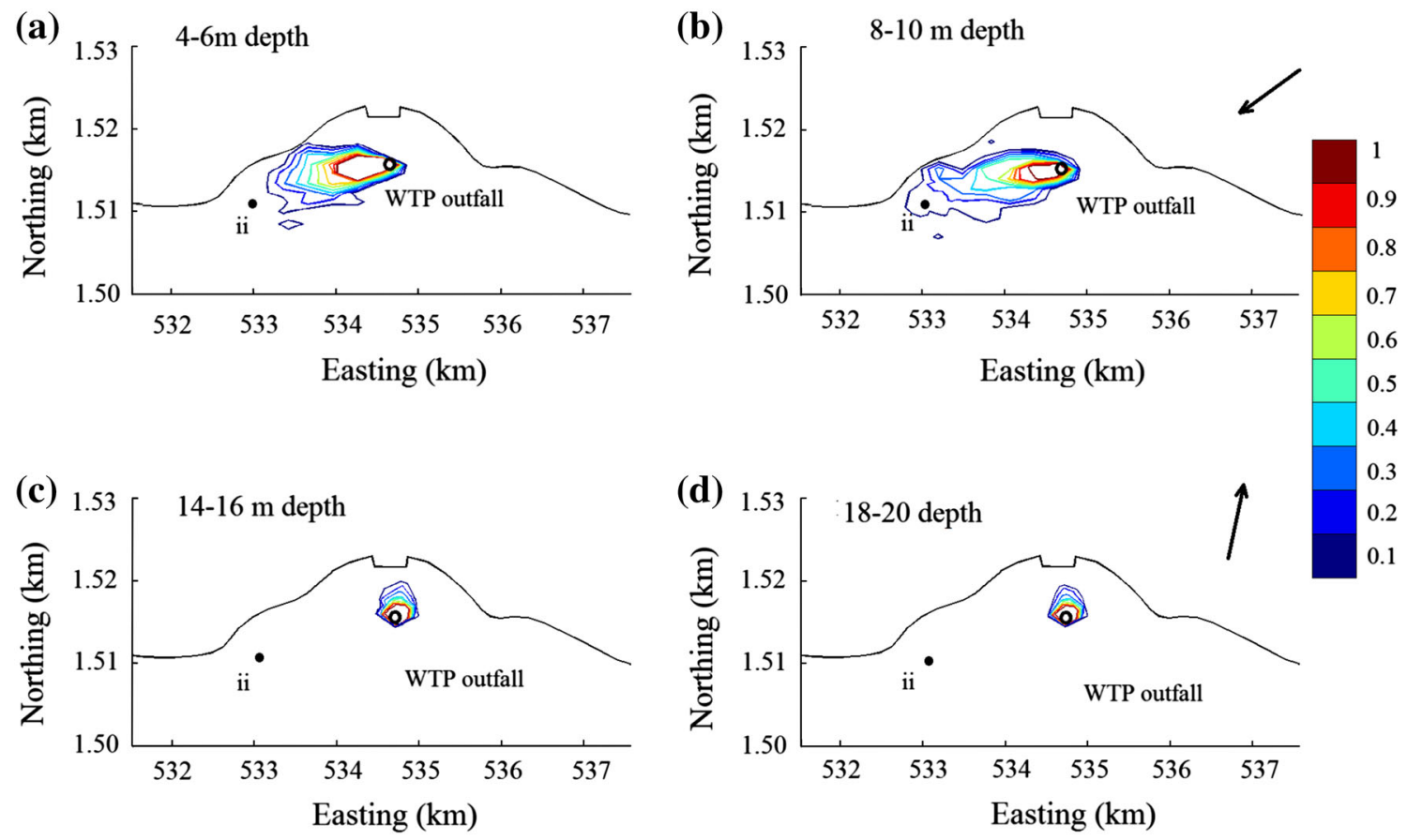

Fig. 2 Predicted normalized concentrations (values given by the color scale) around the WTP outfall on 7 April 2010 (a, b) and 3 May 2010 (c, d) at two different depth ranges. The black vectors on the right top of the

a within-embayment gyre with only a small change in wind angle. Gyres occur for winds in the range $0^{\circ}-25^{\circ}$ (Bise) and $180^{\circ}-220^{\circ}$ (Vent). In the present simulations we used representative scenarios comprising those with gyre formation $\left(0^{\circ}, 10^{\circ}\right.$ for Bise and $180^{\circ}, 190^{\circ}$ for Vent $)$ and those without $\left(40^{\circ}\right.$ for Bise, $240^{\circ}$ for Vent). Here we briefly describe the two mechanisms of gyre formation due to Bise and Vent winds. Consistent with previous studies on open embayments (Elwell 2004; McCormick and Schwab 2008), during the Bise, gyre formation is influenced strongly by the current direction in front of Vidy Bay (Razmi et al. 2013). Due to the shoreline recession, the longshore current separates from, and then re-attaches to, the shoreline (Elwell 2004). Razmi et al. (2013) showed that, as the wind angle increases from $0^{\circ}$, the westward longshore current direction is modified on the lake's northern boundary. At the same time, the gyre within Vidy Bay disappears, and is replaced by a westward longshore current within the embayment. The currents are more complex for the Vent. In contrast to the Bise, a $180^{\circ}$ Vent has a long fetch, for which simulations show shoreward currents moving towards the embayment. In the Vidy Bay area, longshore currents are formed, both moving towards the embayment (from the east and west). These create an off-shoreward current located near the middle of the embayment (Razmi et al. 2013). The off-shoreward currents and weak eastward current in front of the embayment generate a gyre. The eastward longshore current velocity in the north-shore

plots show the average wind direction at Pully station (Fig. 1) during the period of the experiments. The plumes, particles were released continuously above the outfall for $6 \mathrm{~h}$ (color figure online)

boundary increases with the Vent angle. The gyre weakens and, at a wind angle of $220^{\circ}$, an eastward longshore current occurs in the embayment.

We considered uniform winds in non-stratified seasons (Table 1). For most scenarios, a moderate wind speed of $3 \mathrm{~m} \mathrm{~s}^{-1}$ was imposed. For comparison, we selected two wind regimes (Bise and Vent) for which 1, 5, and $7 \mathrm{~m} \mathrm{~s}^{-1}$ wind speeds were used (event durations of $\sim 2$ days assumed). For cases involving gyre formation, the magnitude of the circulation in the gyre is given in Table 1 (Razmi et al. 2013).

Overall, 18 scenarios are listed in Table 1. For each scenario, Lake Geneva's currents were simulated using Delft3D-FLOW, with runs continuing until quasi-steady conditions were reached. The results were then used for simulating particle tracking from the embayment as indicated in Fig. 1b. Figure 3 displays the time dependence of the relative concentration averaged over the whole embayment, $N(t) / N(0)$, versus $t$ for selected scenarios from Table 1.

Initially, all the tracers are inside the embayment so $T^{*}=0$ and $N(t=0) / N(0)=1$. Thereafter, $N(t) / N(0)$ decreases (Fig. 3) as particles leave the embayment. $T^{*}(t)$ converges smoothly to the limiting value, $T$. Table 1 provides calculated residence times for each scenario. It is apparent from Fig. 3 that the results fall into two main classes, i.e., cases with gyres and those without. For the former (e.g., CASE 1_10), the residence time is about 
Table 1 Cases examined (differentiated mainly by wind angle)

\begin{tabular}{lllllr}
\hline Case & $\begin{array}{l}\text { Circulation } \\
\left(\mathrm{m}^{2} \mathrm{~s}^{-1}\right)\end{array}$ & $\begin{array}{l}\text { Wind } \\
\text { regime }\end{array}$ & $\begin{array}{l}\text { Wind } \\
\text { angle }\end{array}$ & $\begin{array}{l}\text { Wind speed } \\
\left(\mathrm{m} \mathrm{s}^{-1}\right)\end{array}$ & $T(\mathrm{~h})$ \\
\hline CASE 1_0 & 55 & Bise & $0^{\circ}$ & 3 & 175 \\
CASE 2_10 & 32 & Bise & $10^{\circ}$ & 3 & 102 \\
CASE 3_40 & - & Bise & $40^{\circ}$ & 3 & 46 \\
CASE 4_180 & 56 & Vent & $180^{\circ}$ & 3 & 179 \\
CASE 5_190 & 22 & Vent & $190^{\circ}$ & 3 & 43 \\
CASE 6_240 & - & Vent & $240^{\circ}$ & 3 & 31 \\
CASE 7_10 & 12 & Bise & $10^{\circ}$ & 1 & 228 \\
CASE 8_40 & - & Bise & $40^{\circ}$ & 1 & 112 \\
CASE 9_10 & 44 & Bise & $10^{\circ}$ & 5 & 63 \\
CASE 10_40 & - & Bise & $40^{\circ}$ & 5 & 32 \\
CASE 11_10 & 71 & Bise & $10^{\circ}$ & 7 & 44 \\
CASE 12_40 & - & Bise & $40^{\circ}$ & 7 & 26 \\
CASE 13_190 & 13 & Vent & $190^{\circ}$ & 1 & 167 \\
CASE 14_240 & - & Vent & $240^{\circ}$ & 1 & 91 \\
CASE 15_190 & 40 & Vent & $190^{\circ}$ & 5 & 33 \\
CASE 16_240 & - & Vent & $240^{\circ}$ & 5 & 24 \\
CASE 17_190 & 63 & Vent & $190^{\circ}$ & 7 & 20 \\
CASE 18_240 & - & Vent & $240^{\circ}$ & 7 & 17 \\
\hline
\end{tabular}

The embayment (Fig. 1b) residence time for each case is included. Gyre formation (and magnitude) is indicated by entries in the "Circulation" column

${ }^{a} 0^{\circ}$ is north, angles measured clockwise

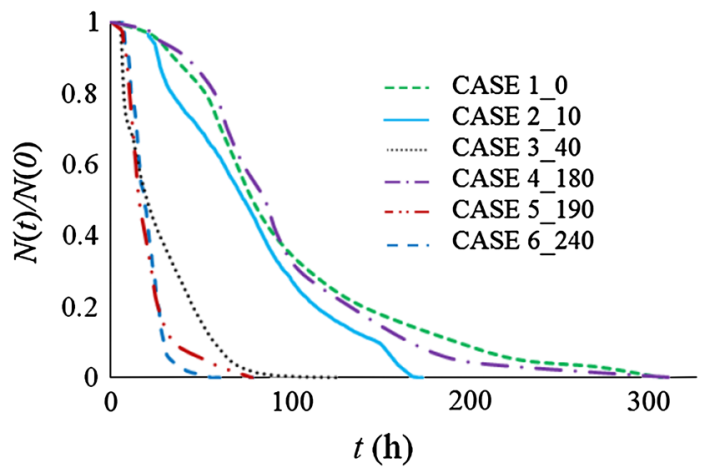

Fig. 3 Time dependence of particle concentrations in the embayment, $N(t) / N(0)$. Two distinct current patterns in the embayment are evident: gyres and longshore currents

twice as large as for cases without gyres (e.g., CASE 3_40). The residence time changes with the mean wind speed, and its variability increases substantially when gyres are present (Fig. 3). In the following, we discuss the results based on the wind regime characteristics, including cases with/without gyre formation in the embayment (Table 2).

\section{Wind regimes}

It is clear from Fig. 3 that the residence times partition into two classes, with only limited variation within each type.
Table 2 Travel times (h) \pm one standard deviation for water parcels to leave the embayment from the three potential sources of pollution (shown in Fig. 1a) in Vidy Bay

\begin{tabular}{llll}
\hline Case & $\begin{array}{l}\text { WTP outfall } \\
\text { (h) }\end{array}$ & $\begin{array}{l}\text { Flon drain } \\
\text { (h) }\end{array}$ & $\begin{array}{l}\text { Chamberonne } \\
\text { River (h) }\end{array}$ \\
\hline CASE 2_10 & $25 \pm 3.1$ & $27 \pm 2.9$ & $26 \pm 2.5$ \\
CASE 3_40 & $20 \pm 3.3$ & $25 \pm 2.6$ & $21 \pm 2.2$ \\
CASE 5_190 & $24 \pm 3.0$ & $14 \pm 2.3$ & $21 \pm 2.0$ \\
CASE 6_240 & $10 \pm 1.8$ & $8 \pm 1.5$ & $11 \pm 1.7$ \\
\hline
\end{tabular}

These two characteristic residence times are presented in figure S4, which shows the probability density function (PDF) for the particle travel time (the average of which is the embayment residence time) for CASEs 1-6. With a gyre, the travel time PDF is far flatter, has a much lower peak with far greater standard deviation (e.g., standard deviation in CASE 4 is $\sim 5$ times of CASE 5). Clearly, the gyre increases the probability that water parcels are retained in the embayment for longer durations than for cases without a gyre. Figure 4 displays the average residence time $(T)$ and standard deviation for each case in Table 1. For the Bise cases, as the wind angle increases from $0^{\circ}$, the parallel-to-shore component of the wind forcing increases. Consequently, westward longshore currents on the lake's northern boundary increase, and circulation within the embayment decreases, as does the residence time. For instance, the residence time decreases from CASE 1_0 $(T \sim 175 \mathrm{~h})$ to CASE 2_10 $(T \sim 102 \mathrm{~h})$ (Fig. 4). For wind angles greater than $25^{\circ}$, westward longshore currents are dominant, and rapidly flush most of the water from the embayment (with a correspondingly very low residence time, CASE 3_40, $T \sim 46 \mathrm{~h}$ ).

The residence times for onshore wind cases (CASE 4_180, CASE 5_190, Table 1) are higher than other Vent directions (CASE 6_240, Table 1). The residence time decreases as the wind angle increases (i.e., from CASE 5_190 to CASE 6_240) due to greater prevalence of longshore currents, and weaker gyres. As the wind angle becomes more parallel-to-shore (i.e., eastward), strong eastward longshore currents dominate, gyres weaken and eventually disappear. These strong longshore currents lead to a short residence time in the embayment (Fig. 4). The residence time for Vent winds from $180^{\circ}$ to $190^{\circ}$ dropped significantly because of strong eastward longshore currents generated in the latter case. Such currents limit gyre formation in the embayment. Although there is a weak gyre for the $190^{\circ}$ Vent, it does not impact much on residence time compared with the $240^{\circ}$ Vent, for which no gyre forms, in which case $T$ for the $190^{\circ}$ Vent is not markedly greater than that for the $240^{\circ}$ Vent.

The fetch for the Vent winds reaching Vidy Bay (up to about $40 \mathrm{~km}$ ) is much greater than for the Bise (Fig. 1a). 


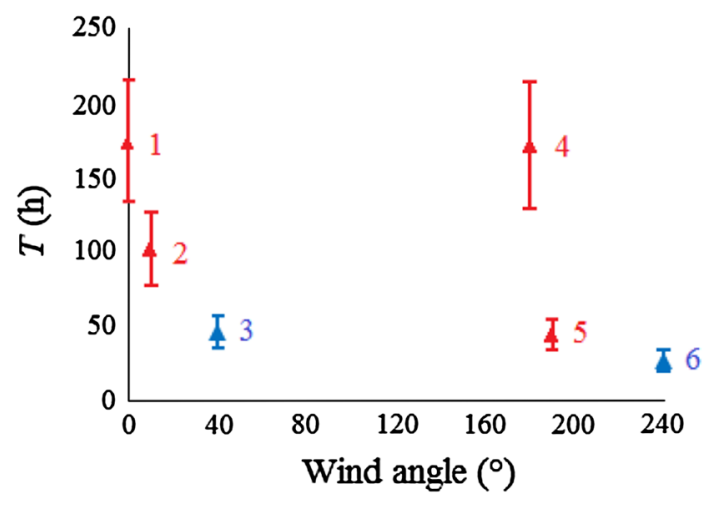

Fig. 4 Averaged embayment residence time $(T)$ and standard deviation of the particle travel time for CASEs $1-6\left(0^{\circ}, 10^{\circ}, 40^{\circ}, 180^{\circ}, 190^{\circ}\right.$, and $240^{\circ}$ ). Gyre formation is the dominant factor controlling T. Red and blue show the gyre and no gyre cases, respectively (color figure online)

The eastern half of Lake Geneva is surrounded by mountains, in contrast to the gentle topography surrounding the western half of the lake. In Vent conditions, the large scale circulation in the lake drives strong eastward currents in the pelagic zone near the north shore of the lake. Additionally, at Vidy Bay, local winds push the water towards the shore. The combination of these two factors causes more rapid longshore currents for the Vent compared to the Bise (Table 1).

\section{Wind speed}

The impact of different wind speeds on the residence time of Vidy Bay was assessed for both Bise and Vent winds. Four different wind speeds were selected, with results given in Fig. 5. Not surprisingly, the residence time decreases as the wind speed increases. However, the rate of change decreases with increasing wind speed.

Travel times for potential pollution sources in the embayment

Here, we consider travel times for water entering Vidy Bay at the WTP outfall discharge, Flon drain and Chamberonne River (Fig. 1a). These simulations were performed to estimate the duration that potential pollutants from these sources remain in Vidy Bay. Particle tracking was performed separately for each potential pollutant source for the dominant wind regimes. In all, four cases were selected, CASE 2_10 and CASE 3_40 for the Bise and CASE 5_190 and CASE 6_240 for the Vent (Table 1). Since the selected discharge points all contribute to the residence time of the embayment, individual travel times to exit from the embayment could be greater or less than the corresponding embayment residence times.

We examined travel times for representative cases for the three inputs mentioned above. Since wind is the main

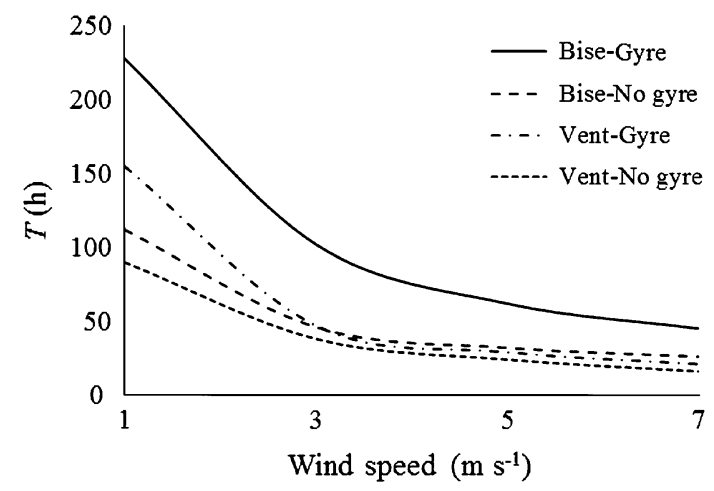

Fig. 5 Variation of the residence time $(T)$ with wind speed for Bise $\left(10^{\circ}\right.$ and $\left.40^{\circ}\right)$ and Vent $\left(190^{\circ}\right.$ and $\left.240^{\circ}\right)$ regimes

factor influencing the current patterns, the present study focuses on the effect of wind conditions on the travel time variability of the effluents in the embayment. For the WTP outfall, particles were placed in the near-surface layer (0-10 $\mathrm{m}$ depth). For the Chamberonne River and Flon drain, since the discharges are located at the shoreline, we assumed that the input rapidly mixed in the near-surface layer. Thus, particles were released in the $0-5 \mathrm{~m}$ depth range.

Before looking at the travel times themselves, we consider typical cases that form the basis of the computed travel times. Figure 6 compares two representative cases: with (CASE 2_10) and without (CASE 3_40) gyres. The plots show the time evolution of the particle tracks (50 particles) during $90 \mathrm{~h}$ simulation following release from the near-surface layer above the WTP outfall. In CASE 2_10 (Fig. 6a), during the first $\sim 25 \mathrm{~h}$ the particles are mixed around the release point, after which most move toward the southwest where they leave the embayment. In other words, there is considerable mixing within the embayment. We recall that the residence time of the entire embayment for this case is also large $(102 \mathrm{~h}$, Table 1$)$. However, in CASE 3_40 (Fig. 6b), the picture is more straightforward: Most particles move westwards along the shore and leave the embayment relatively quickly. Still, the tracks shown in Fig. 6a indicate that some particles are recirculated and thus increase the residence time as in CASE 2_10.

As was the case in "Residence times for different characteristic wind regimes and thermal stratification", when longshore currents are dominant, current speeds in the embayment are greater for the Vent than for the Bise scenarios. For the cases without gyre formation in the embayment (i.e., CASE 3_40 and CASE 6_240), the travel times with stratification are less than those for the corresponding cases without stratification. In the cases with gyre formation, results are the same as discussed above in "Residence times for different characteristic wind regimes 


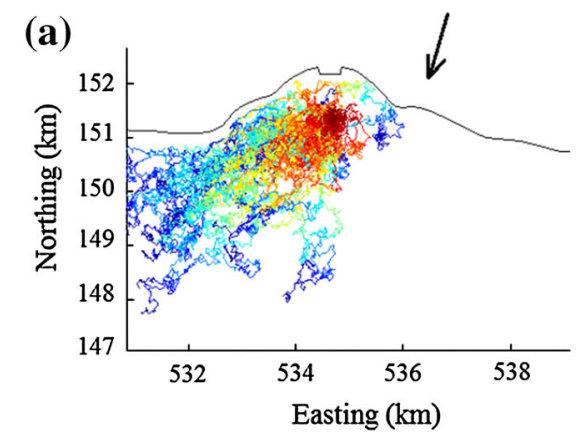

Fig. 6 Particle tracking for two distinct scenarios: a with a gyre (CASE $2 \_10$ ) and $\mathbf{b}$ with a predominantly longshore current (CASE 3_40). The color bar indicates the time since particle release. The results are based

and thermal stratification". Gyre formation is more effective at increasing residence time than other factors.

Implications for the Lausanne water intake

Of the inputs into the embayment, the WTP outfall has the greatest potential for introducing pollutants (e.g., Poté et al. 2009; Bonvin et al. 2011). Consequently, we concentrate on the WTP discharge and assess the potential for pollutants to reach the main Lausanne drinking water intake, which is about $3.7 \mathrm{~km}$ distant at a depth of about $50 \mathrm{~m}$, just above the lakebed (Fig. 1a). Our analysis ignores local vertical motion of the water. The 2010 Delft3D-FLOW simulation results were used. We analyzed winds (Pully meteorological station) and simulated current directions for the vertical column above the WTP outfall. The rationale for this approach is that one can easily determine the wind

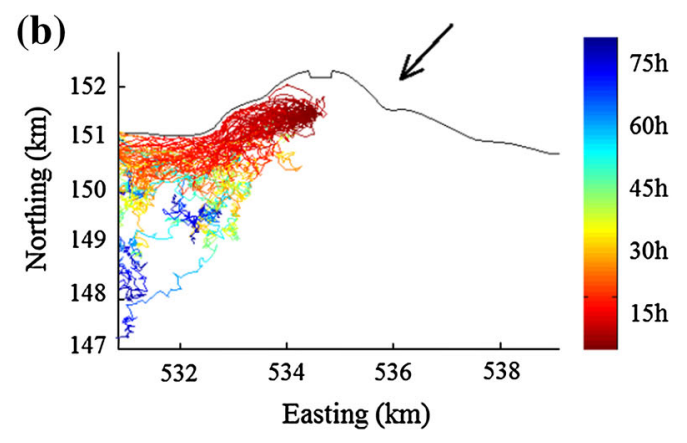

on instantaneous release for 50 particles released from the grid cell above the WTP discharge point at $\sim 5-\mathrm{m}$ depth. The black vectors on the right top of the plots show wind directions (color figure online)

direction in Vidy Bay from near real-time data from the nearby Pully meteorological station (MeteoSwisse 2013). From this limited information, we wish to estimate the probability of a given current direction above the WTP outfall.

We broadly defined the wind direction based on the wind regimes as measured at Pully station. Thus, we designated wind regimes as $i=1\left(\mathrm{Bise}, 0^{\circ}-25^{\circ}\right)$, associated with the gyre formation, $i=2$ (Bise, $25^{\circ}-70^{\circ}$ ), associated with the westward longshore current in the embayment, and $i=3$ (Vent, $180^{\circ}-320^{\circ}$ ), which is mainly associated with eastward longshore currents. All other winds were designated as $i=4$ (i.e., winds from $70^{\circ}$ to $180^{\circ}$ and $320^{\circ}$ to $360^{\circ}$ ). Currents above the WTP outfall were divided into four direction ranges, denoted by $j=1,2,3,4$ in Table 3 , where the current direction ranges are also provided. Current direction $j=1$ represents westward longshore

Table 3 Conditional probability of current directions in the water column above the Vidy Bay WTP outfall, $j$, based on wind regimes, $i$

\begin{tabular}{|c|c|c|c|c|c|c|}
\hline Layer & Wind regime ${ }^{\mathrm{a}}$ & $P(i)$ & $P(i) P(j=1 \mid i)$ & $P(i) P(j=2 \mid i)$ & $P(i) P(j=3 \mid i)$ & $P(i) P(j=4 \mid i)$ \\
\hline \multirow[t]{4}{*}{ Near-surface } & Bise $(i=1)$ & 0.23 & 0.09 & 0.07 & 0.03 & 0.04 \\
\hline & Bise $(i=2)$ & 0.31 & 0.21 & 0.05 & 0.02 & 0.03 \\
\hline & Vent $(i=3)$ & 0.35 & 0.10 & 0.17 & 0.05 & 0.03 \\
\hline & Others $(i=4)$ & 0.11 & 0.04 & 0.03 & 0.02 & 0.02 \\
\hline \multirow[t]{4}{*}{ Mid-level } & Bise $(i=1)$ & 0.23 & 0.08 & 0.06 & 0.03 & 0.06 \\
\hline & Bise $(i=2)$ & 0.31 & 0.19 & 0.06 & 0.02 & 0.04 \\
\hline & Vent $(i=3)$ & 0.35 & 0.10 & 0.15 & 0.04 & 0.06 \\
\hline & Others $(i=4)$ & 0.11 & 0.05 & 0.03 & 0.02 & 0.01 \\
\hline \multirow[t]{4}{*}{ Near-bottom } & Bise $(i=1)$ & 0.23 & 0.09 & 0.05 & 0.04 & 0.05 \\
\hline & Bise $(i=2)$ & 0.31 & 0.18 & 0.04 & 0.06 & 0.03 \\
\hline & Vent $(i=3)$ & 0.35 & 0.11 & 0.09 & 0.08 & 0.07 \\
\hline & Others $(i=4)$ & 0.11 & 0.04 & 0.02 & 0.03 & 0.02 \\
\hline
\end{tabular}

Wind regimes refer to wind directions as measured at the nearby Pully meteorological station. Different layers in the water column are considered, i.e., near-surface (top $5 \mathrm{~m})$, mid-level (10-15 m depth) and near-bottom (25-30 m depth)

${ }^{\mathrm{a}}$ Wind regimes (as measured at Pully station): $i=1$ (Bise, $0^{\circ}-25^{\circ}$ ), $i=2$ (Bise, $25^{\circ}-70^{\circ}$ ), $i=3$ (Vent, $180^{\circ}-320^{\circ}$ ), $i=4($ other winds from $70^{\circ}$ to $180^{\circ}$ and $320^{\circ}$ to $\left.360^{\circ}\right)$. Current regimes (as measured above the Vidy Bay outfall): $j=1\left(250^{\circ}-340^{\circ}\right), j=2\left(70^{\circ}-160^{\circ}\right), j=3\left(160^{\circ}-\right.$ $\left.250^{\circ}\right), j=4\left(340^{\circ}-360^{\circ}\right.$ and $\left.0^{\circ}-70^{\circ}\right)$. Wind and current angles are based on "coming from" and "going to" directions, respectively 
currents, which are predominantly responsible for water parcel transport from the WTP outfall to the drinking water intake location. The interpretation of other current directions is: $j=2$-eastward parallel-to-shore, $j=3$ offshore, and $j=4$-onshore. The probabilities of currents for $j=1-4$ are presented in Table 3 for the near-surface layer, mid-layers and near-bottom layers of the water column.

The conditional probabilities of each of the four current directions based on the four wind regimes in the nearsurface, subsurface, and near-bottom layers above the outfall are provided in Table 3. The worst case for the Lausanne drinking water intake is westward $(j=1)$ currents, for which gyres do not occur. Unsurprisingly, these are most probable for the Bise wind angles in the range $25^{\circ}-70^{\circ}(i=2)$, which occur about $20 \%$ of the time. For this case, the travel time from the WTP outfall to the Lausanne water intake was estimated as about $13 \mathrm{~h}$.

\section{Concluding remarks}

In this study, we determined the residence time for Vidy Bay under different wind conditions for the purpose of providing information relevant to pollutant transport in the embayment. Vidy Bay is particularly interesting: It is an archetype of an embayment type that, at first sight, would be expected to be readily flushed due to its geometrical characteristics (Fig. 1a). However, the embayment is much larger than that suggested on purely geometrical grounds, since it hosts significant gyres under certain wind conditions. Such gyres increase the residence time within the embayment.

Results from a previous field campaign were used for checking the combined flow and particle modeling approach. The field campaign was designed to investigate the spatio-temporal evolution of micropollutant concentrations, although on most occasions only background concentrations were detected. The model gave results that are consistent with the field data. The value of modeling is clear in these circumstances-the field data considered alone offer only limited insights into current directions since on most occasions the WTP effluent plume did not move parallel to shore, as the field sampling strategy hypothesized.

The residence time results are sensitive to wind angle, since small changes in the wind angle can lead to significant changes in current patterns. However, despite the wide variety of current patterns that can occur, for a given wind speed essentially there are two types of residence time distribution, one for cases with gyre formation (long residence time in excess of $100 \mathrm{~h}$ ) and one for longshore currents (much shorter residence time of up to about $50 \mathrm{~h}$ ).
The probability density function for the former case also has a larger standard deviation than the latter, not surprisingly given the different physical circumstances underlying each of the two categories identified. More precisely, for winds with a longshore component, water movement is more parallel to the shore for both the littoral and pelagic zones and gyres are less likely to form in the embayment. In contrast, on- or off-shore winds are more likely to produce gyres within the embayment, which considerably increase the residence time. We have considered a range of typical scenarios, but the results in Table 1 provide estimates of residence times mainly for a single wind speed. A rough extrapolation of these results is possible using Fig. 5, which considers a range of wind speeds. The residence time is reduced with increasing the wind speed, as expected since the wind angle is the main determinant of the different current patterns.

The specific issue of water from the WTP outfall in Vidy Bay reaching the Lausanne water intake roughly $3.7 \mathrm{~km}$ to the west was considered in some detail. The most problematic meteorological situation is a Bise wind with a longshore component, since it produce westward parallelto-shore currents. Such cases were shown to produce highly diluted tracer concentrations in the water column above the water intake. To provide more detail for this case, we considered current simulations for all of 2010 (i.e., using variable wind fields from COSMO), from which we estimated the probability of currents suitable to move water to the Lausanne intake. Overall, water parcels from the WTP discharge reached the water column above the Lausanne water intake about $20 \%$ of the time. For this scenario, the travel time from the WTP discharge to the Lausanne water intake is typically about $13 \mathrm{~h}$, although our modeling does not consider the vertical extent of the local capture zone of the intake.

Acknowledgments This publication is part of the international, interdisciplinary research project ELEMO (http://www.elemo.ch) to investigate the deep-waters of Lake Geneva using two Russian MIR submarines. Funding for this study was provided by the Fondation pour l'Etude des Eaux du Léman (FEEL) and the Swiss National Foundation (PDFMP2-123034/1). We thank Jean-Denis Bourquin for providing administrative support. The authors thank the three anonymous reviewers and the editor for their useful comments.

\section{References}

Appelo CAJ, Postma D (2005) Geochemistry, groundwater and pollution. Taylor and Francis, Amsterdam

Bohle-Carbonell M (1986) Currents in Lake Geneva. Limnol Oceanogr 31:1255-1266. doi:10.4319/lo.1986.31.6.1255

Bonvin F, Rutler R, Chèvre N, Halder J, Kohn T (2011) Spatial and temporal presence of a wastewater-derived micropollutant plume in Lake Geneva. Environ Sci Technol 45:4702-4709. doi:10. $1021 /$ es 2003588 
Bonvin F, Razmi AM, Barry DA, Kohn T (2013) A coupled hydrodynamic-photolysis model to simulate the fate of micropollutants in Vidy Bay. Environ Sci Technol 47:9207-9216. doi:10.1021/es401294c

Brookes JD, Antenucci J, Hipsey M, Burch MD, Ashbolt NJ, Ferguson C (2004) Fate and transport of pathogens in lakes and reservoirs. Environ Int 5:741-759. doi:10.1016/j.envint.2003.11. 006

Buffoni G, Falco P, Griffa A, Zambianchi E (1997) Dispersion processes and residence times in a semi-enclosed basin with recirculating gyres: an application to the Tyrrhenian Sea. J Geophys Res 102:18699-18713. doi:10.1029/96JC03862

Choi KW, Lee JHW (2004) Numerical determination of flushing time for stratified water bodies. J Mar Syst 50:263-281. doi:10.1016/j. jmarsys.2004.04.005

Cipel. http://www.cipel.org (Accessed 10 Sep 2013)

COSMO. http://www.cosmo-modelorg/content/model/documentation/ core/default.htm (Accessed 10 Sep 2013)

Daughton CG, Ternes TA (1999) Pharmaceuticals and personal care products in the environment: agents of subtle change? Environ Health Perspect 107:907-938. doi:10.1007/b11992

Delf3D-PART, User Manual 2009, Version: 2.13, Revision: 6359. http://www.deltaressystems.com/hydro/product/621497/delft3dsuite (Accessed 10 Sep 2013)

Delft3D-FLOW, User Manual 2011, Version: 3.15, Revision: 17474. http://www.deltaressystems.com/hydro/product/621497/delft3dsuite (Accessed 10 Sep 2013)

Elwell FC (2004) Flushing of embayments. Unpublished PhD thesis, Queens' College, Cambridge. http://www.damtp.cam.ac.uk/lab/ people/fcg21/thesis.pdf

Falconer RA, George D, Hall P (1991) Three-dimensional numerical modeling of wind-driven circulation in a shallow homogenous lake. J Hydrol 124:59-79. doi:10.1016/j.advwatres.2004.08.004

Gascon Diez E, Bravo AG, Porta N, Masson M, Graham ND, Stoll S, Akhtman Y, Amouroux D, Loizeau JL (2013) Mercury content and speciation related to sediment surface patterns in contaminated Vidy Bay, Lake Geneva, Switzerland. Aquat Sci (this issue)

Ge ZF, Nevers MB, Schwab DJ, Whitman RL (2010) Coastal loading and transport of Escherichia coli at an embayed beach in Lake Michigan. Environ Sci Technol 44:6731-6737. doi:10.1021/ es100797r

George DG, Edwards RW (1976) The effect of wind on the distribution of chlorophyll and crustacean plankton in a shallow eutrophic reservoir. J Appl Ecol 13:667-690. http://www.jstor. org/stable/2402246

Gill AE (1982) Atmosphere-ocean dynamics. Int Geophys Series, vol 30. Academic Press. San Diego

Haldimann S (2010) Modélisation des rejets lausannois dans le Léman. Schweiz Verein des Gas- und Wasserfaches. 3:209-220

Harris EL, Falconer RA, Lin B (2004) Modeling hydroenvironmental and health risk assessment parameters along the South Wales Coast. J Environ Manage 73:61-70. doi:10.1038/leu.2012.326

Hipsey MR, Antenucci JP, Brookes JD (2008) A generic, processbased model of microbial pollution in aquatic systems. Water Resour Res 44:W07408. doi:10.1029/2007WR006395

Hoerger CC, Akhtman Y, Martelletti L, Rutler R, Bonvin F, Grange A, Arey JS, Kohn T (2013) Spatial extent and ecotoxicological risk assessment of a micropollutant-contaminated wastewater mass in Lake Geneva. Aquat Sci (this issue)

Jackson TR, Haggerty R, Apte SV, Coleman A, Drost KJ (2012) Defining and measuring the mean residence time of lateral surface transient storage zones in small streams. Water Resour Res 48:W10501. doi:10.1029/2012WR012096

Ji Z (2008) Hydrodynamics and water quality: modeling rivers, lakes, and estuaries. Wiley, New Jersey
Kristal D, Anderson MA, Yates MV (2005) Distribution of indicator bacteria in Canyon Lake, California. Water Res 39:1277-1288. doi:10.1016/j.watres.2005.01.011

Lemmin U, D'Adamo N (1996) Summertime winds and direct cyclonic circulation: observations from Lake Geneva. Ann Geophys 14:1207-1220. doi:10.1007/s00585-996-1207-z

Lesser GR, Roelvink JA, Van Kester JATM, Stelling GS (2004) Development and validation of a three-dimensional morphological model. Coast Eng 51:883-915. doi:10.1016/j.coastaleng. 2004.07.014

Margot J, Kienle C, Magnet A, Weil M, Rossi L, de Alencastro LF, Abegglen C, Thonney D, Chèvre N, Schärer M, Barry DA (2013) Treatment of micropollutants in municipal wastewater: ozone or powdered activated carbon? Sci Total Environ 7:480-498. doi:10.1016/j.scitotenv.2013.05.034

Masson M, Tercier-Waeber ML (2013) Trace metal speciation at the sediment-water interface of the Vidy Bay: influence of contrasting sediment characteristics. Aquat Sci (this issue)

McCormick MJ, Schwab DJ (2008) Observations of currents in Saginaw Bay, Lake Huron. Aquat Ecosyst Health Manage 11:182-189. doi:10.1080/14634980802092997

MeteoSwisse. http://www.meteoswiss.admin.ch (Accessed 10 Sep 2013)

Okubo A (1973) Effect of shoreline irregularities on streamwise dispersion in estuaries and other embayments. Netherlands J Sea Res 6:213-224

Oulton RL, Kohn T, Cwiertny DM (2010) Pharmaceuticals and personal care products in effluent matrices: a survey of transformation and removal during wastewater treatment and implications for wastewater management. J Environ Monit 12:1956-1978. doi:10.1039/c0em00068j

Peeters F, Wüest A, Piepke G, Imbeden DM (1996) Horizontal mixing in lakes. J Geophys Res 101:18361-18375. doi:10.1029/ 96JC01145

Poté J, Goldscheider N, Haller L, Zopfi J, Khajehnouri F, Wildi W (2009) Origin and spatial-temporal distribution of faecal bacteria in a bay of Lake Geneva, Switzerland. Environ Monit Assess 154:337-348. doi:10.1007/s10661-008-0401-8

Razmi AM, Barry DA, Bakhtyar R, Le Dantec N, Dastgheib A, Lemmin U, Wüest A (2013) Current variability in a wide and open lacustrine embayment in Lake Geneva (Switzerland). J Great Lakes Res 39:455-465. doi:10.1016/j.jglr.2013.06.011

Rueda FJ, Cowen EA (2005) Exchange between a freshwater embayment and a large lake through a long, shallow channel. Limnol Oceanogr 50:169-183. doi:10.4319/lo.2005.50.1.0169

Sauvain L, Bueche M, Junier T, Masson M, Wunderlin T, KohlerMilleret R, Gascon Diez E, Loizeau JL, Tercier-Waeber ML, Junier P (2013) Bacterial communities in trace metal contaminated lake sediments are dominated by endospore-forming bacteria. Aquat Sci (this issue)

Scavia D, Bennett JR (1980) Spring transition period in Lake Ontario-a numerical study of the causes of the large biological and chemical gradients. Can J Fish Aquat Sci 37:823-833. doi:10.1139/f80-111

Schladow SG, Hamilton DP (1997) Prediction of water quality in lakes and reservoirs: part II-model calibration, sensitivity analysis and application. Ecol Model 96:111-123. doi:10.1016/ S0304-3800(96)00063-4

Singell RP, Beardsley RC, Graber HC, Capotondi A (1990) Effect of wave-current interaction on wind-driven circulation in narrow, shallow embayments. J Geophys Res 95:9671-9678. doi:10. 1029/JC095iC06p09671

Soulsby RL (1997) Dynamics of marine sands. Thomas Telford, HR Wallingford, London

Swiss coordinates. http://www.swisstopo.admin.ch (Accessed 10 Sep 2013) 
Wüest A, Lorke A (2003) Small-scale hydrodynamics in lakes. Annu Rev Fluid Mech 35:373-412. doi:10.1146/annurev.fluid.35.101101. 161220

Wüest A, Anselmetti FS, Arey JS, Ibelings BW, Loizeau JL, Vennemann T, Lemmin U (2013) Into the abyss of Lake Geneva-interdisciplinary field investigations using the MIR submersibles. Aquat Sci (this issue)
Wunderlin T, Corella JP, Junier T, Bueche M, Loizeau JL, Girardclos S, Junier P (2013) Endospore-forming bacteria as new proxies to assess impact of eutrophication in Lake Geneva (SwitzerlandFrance). Aquat Sci (this issue) 